\title{
Gadai Emas Pada Lembaga Keuangan Syariah
}

\author{
Abd. Rauf AR Barri ${ }^{1}$ \\ ${ }^{1}$ UIN Alauddin Makassar \\ E-mail : abd.rauf@gmail.com
}

\begin{abstract}
Abstrak,
Pokok masalah penelitian ini adalah bagaimana implementasi gadai emas pada lembaga keuangan syariah di Makassar (studi kasus pada PT Bank Sulselbar Syariah). metode pengumpulan data yang digunakan adalah observasi, wawancara, dokumentasi, dan penelusuran referensi. Lalu, teknik pengolahan dan analisis data dilakukan dengan dua model yaitu mereduksi data, penyajian data dan penarikan kesimpulan/verifikasi. Hasil penelitian menunjukkan bahwa implementasi gadai emas di PT Bank Sulselbar Syariah sudah sesuai dengan Fatwa Dewan Syariah Majelis Ulama Indonesia No: 25/DSNMUI/III/ 2002, tentang Rahn dan Fatwa Dewan Syariah Nasional Majelis Ulama Indonesia No: 26/DSNMUI/III/2002, tentang Rahn Emas. Ini dibuktikan dengan akad qardh untuk mengikat jaminan ketika terjadi pembiayaan dan Akad ijarah dalam penitipan emas (barang jaminan) kepada bank dan nasabah wajib membayar biaya penitipan sesuai dengan kesepakatan dan ketentuan bank. Dalam proses penyelesaian sengketa antara nasabah dan bank lebih kepada musyawara dan mufakat. Apabila tidak tercapai mufakat para pihak sepakat untuk menyelesaikan melalui badan arbitrase atau melalui Pengadilan Agama.
\end{abstract}

Kata Kunci: Gadai Emas, Lembaga Keuangan Syariah, DSN MUI.

\section{PENDAHULUAN}

Kehadiran Islam menandai berkembangnnya peradaban baru yang sangat mengagumkan dalam segi kebudayaan, ilmu pengetahuan, teknologi serta kehidupan sosial lainnya termasuk ekonomi. Islam adalah agama yang sempurna yang mempunyai sistim tersendiri dalam menghadapi permasalahan kehidupan, baik yang bersifat materi maupun nonmateri. Oleh sebab itu, ekonomi sebagai satu aspek kehidupan, tentu juga sudah diatur oleh Islam, maka mustahil jika Islam tidak dilengkapi dengan sistim dan konsep ekonomi sebagai panduan bagi manusia menjalankan kegiatan ekonomi. (Nasution, 2010)

Perkembangan ekonomi Islam pada saat ini menunjukkan perkembangan yang pesat. Perkembangan produk-produk yang berbasis Islam kian marak di Indonesia, baik itu perbankan syariah maupun pegadaian syariah. Perbankan syariah mengeluarkan produk berbasis Islam yang memberikan kemudahan kepada masyarakat. Perkembangan lembaga keuangan syariah ini mulai terlihat dengan munculnya bank yang berbasis syariah yang pertama yakni, Bank Muamalat Indonesia yang disingkat BMI tahun 1992, dimana pada saat terjadi krisis ekonomi tahun 1997 bank syariah ini mampu lolos dari likuidasi Bank Indonesia. (Arifin, 2005)

Seiring dengan perkembangan sektor perbankan di Indonesia, bank-bank yang ada berusaha untuk selalu meningkatkan kualitas dan kuantitas pelayanannya guna menarik nasabah baru dan juga untuk menjaga loyalitas nasabah lama. Hal tersebut berlaku pula untuk 
perkembangan perbankan syariah saat ini yang semakin menunjukan tren positif. Tidak hanya pasarnya yang kian besar, perbankan syariah juga terus mengeluarkan berbagai produk unggulan yang diminati masyarakat. Konsepnya yang jauh dari riba dan sesuai dengan syariat Islam, membuat produk perbankan syariah menjadi pilihan umat Muslim di Indonesia yang berniat menjalankan agama secara kaffah. (Suryati)

Dalam Islam riba dapat didefinisikan sebagai "premi" yang harus dibayar dari si peminjam kepada yang meminjamkan bersama dengan jumlah pokoknya sebagai kondisi dari jatuh tempo atau berakhirnya masa pinjaman. Sesuai dengan yang disebutkan dalam QS. AlBaqarah/2 : 278-279 yaitu:

Terjemahnya:

Hai orang-orang yang beriman, bertakwalah kepada Allah dan tinggalkan sisa riba (yang belum dipungut) jika kamu orang-orang yang beriman. Maka jika kamu tidak mengerjakan (meninggalkan sisa riba), Maka ketahuilah, bahwa Allah dan rasul-Nya akan memerangimu. dan jika kamu bertaubat (dari pengambilan riba), Maka bagimu pokok hartamu; kamu tidak menganiaya dan tidak (pula) dianiaya.

Gadai merupakan salah satu kategori dari perjanjian utang-piutang, yang mana untuk suatu kepercayaan dari orang yang berpiutang, maka orang yang berutang menggadaikan barangnya sebagai jaminan terhadap utangnya itu. Barang jaminan tetap milik orang yang menggadaikan (orang yang berutang) tetapi dikuasai oleh penerima gadai (yang berpiutang). Namun dalam kenyataan, bahwa gadai yang ada pada saat ini, khususnya di Indonesia dalam praktiknya menunjukkan adanya beberapa hal yang dipandang memberatkan dan dapat mengarahkan kepada suatu persoalan riba. Hal ini dapat dilihat dari praktik pelaksanaan gadai itu sendiri yang secara ketat menentukan bunga gadai, yaitu adanya tambahan sejumlah uang atau persentase tertentu dari pokok utang pada waktu membayar utang. (Soemitra, 2009)

Hadirnya pegadaian sebagai sebuah lembaga keuangan formal di Indonesia, yang bertugas menyalurkan pembiayaan dengan bentuk pemberian uang pinjaman kepada masyarakat yang membutuhkan berdasarkan hukum gadai merupakan suatu hal yang perlu disambut positif. Lembaga pegadaian di Indonesia dewasa ini ternyata dalam praktiknya belum dapat terlepas dari berbagai persoalan. Sedangkan persoalan-persoalan yang dihadapi lembaga tersebut amatlah kompleks. Apabila ditinjau dari syariat Islam, dalam aktivitas perjanjian gadai masih terdapat unsur-unsur yang dilarang oleh syara', di antaranya yaitu masih terdapat unsur riba, masyir (spekulasi), ketidakpastian yang cenderung merugikan salah satu pihak. Hal ini juga akan berakibat timbulnya praktik-praktik ketidakadilan serta berakibat munculnya kezaliman yang lain. Oleh karena itu, perlu adanya rekonstruksi sistem operasionalnya dengan maksud untuk menganalisis secara kritis terhadap gejala umum praktik gadai yang di lakukan oleh lembaga keuangan yang ada sekarang ini dari sudut pandang kajian Hukum Islam dengan melakukan pegadaian syariah. (Sholahuddin, 2006)

Perkembangan gadai ( $r a h n)$ saat ini cukup signifikan baik itu dilembaga perbankkan maupun non perbankkan. Hal ini terbukti dengan bank-bank syariah mulai memasukkan gadai yang berupa gadai emas sebagai salah satu produk unggulannya, seperti Bank Sulselbar Syariah telah mempraktikkan produk gadai emas sejak tahun 2012. Bank Sulselbar Syariah meluncurkan produk rahn atau Gadai Emas Berkah iB, untuk mendukung peningkatan perolehan laba. 
Dengan adanya produk gadai emas pada Bank Sulselbar Syariah ini menandakan bahwa Bank Sulselbar Syariah terus berinovasi untuk memberikan kepuasan produk terhadapat nasabahnya. Produk rahn merupakan produk alternatif yang diperuntukkan bagi para nasabah yang ingin mendapatkan pinjaman, dengan syarat menyerahkan barang jaminan berupa emas. Kontruksi dari produk ini adalah bank memberikan fasilitas pinjaman (qardh) yang harus dikembalikan tetap senilai pinjaman. (Sulselbar, t.thn.) Saat ini layanan gadai ini baru dilayani oleh satu kantor cabang syariah yaitu yang ada di Makassar, ke depan akan dilanjutkan dengan pembukaan kantor cabang syariah di Maros, dan Sengkang. Hadirnya produk gadai emas memberikan ruang kepada masyarakat Sulawesi Selatan untuk berinvestasi dengan mudah dan aman dengan menggunakan prinsip-prinsip syariah. Bank Sulselbar Syariah yang merupakan salah satu lembaga yang menyediakan produk tersebut harus tetap dikawal agar tidak ada banker yang melakukan penyimpangan terhadap implementasi sistem atau mekanisme yang tidak sesuai dengan syariah. Hal ini apabila terjadi, maka berdampak buruk atau dapat merusak citra perbankan syariah di mata masyarakat. Sehingga menimbulkan ketidakpercayaan terhadap lembaga keuangan syariah .

\section{LITERATURE REVIEW}

Dalam sebuah kajian ilmiah membutuhkan dukungan teori dari berbagai sumber atau rujukan yang mempunyai relevansi dengan sebuah penelitian, berdasarkan hasil penelusuran literatur pada berbagai sumber pustaka masih sedikit yang mengkaji dan meneliti tentang gadai emas dengan menggunakan prinsip dan akad secara syariah namun terdapat beberapa rujukan dan hasil penelitian yang relevan, di antara literatur yang memiliki kaitan yaitu :

Tesis Tri Pudji Susilowati dengan judul "Pelaksanaan Gadai dengan Sistem Syariah di Perum Pegadaian Semarang”, (Susilowati, 2008) Gadai merupakan lembaga jaminan yang telah sangat dikenal dan dalam kehidupan masyarakat, dalam upayanya untuk mendapatkan dana guna berbagai kebutuhan transaksi hukum gadai dalam fikih Islam disebut gadai (arRahn). Gadai (ar-Rahn) adalah suatu jenis perjanjian untuk menahan suatu barang sebagai tanggungan utang. Dalam tesis tersebut menekankan proses pelaksanaan gadai yang berlandaskan prinsip-prinsip syariah, perlindungan hukum bagi para pihak dalam pelaksanaan gadai dengan sistem syariah dan bagaimana dengan pelaksanaan eksekusi dari gadai dengan sistem syariah apabila terjadi wanprestasi di pegadaian syariah Perum Pegadaian Semarang. Adapun perbedaan pada tesis ini yaitu pada obyek penelitian dan pengkajiannya, sedangkan dalam tesis yang ingin penulis teliti yaitu lembaga perbankan yang menggunakan produk gadai emas yang menggunakan akad dan prinsip secara syariah.

Rina Dahlina, dalam Tesisnya yang berjudul," Kedudukan Lembaga Gadai Syariah (arRahn) Dalam Sistim Perekonomian Islam (Studi Di Bank Muamalat Indonesia Cabang Medan dan Bank BNI Unit Syariah Medan)”. (Dahlina, 2005) (Marhanita, 2012) Penelitian dalam Tesisnya tersebut yaitu lebih bertujuan untuk mengetahui bentuk rahn yang dapat dijadikan jaminkan pada Bank Muamalat Indonesia Cabang Medan dan Bank BNI Unit Syariah Medan dan kedudukan gadai syariah dalam hukum penggadaian di Indonesia. Ada pun dari hasil penelitian menunjukan bahwa Bank BNI Unit Syariah Medan dalam melakukan suatu 
kerjasama dengan menggunakan prinsip musyarakah misalnya dalam suatu proyek yang mana jaminan adalah surat tanda mendapatkan proyek yang bersangkutan, hanya saja dalam keuntungan yang diperoleh sudah diprediksi terlebih dahulu serta jangka waktu kerjasama atau dana yang akan disalurkan dengan jangka pendek yaitu dalam dua bulan sampai satu tahun. Bank Muamalat Indonesia Cabang Medan memberikan produk (ar-Rahn) untuk masyarakat menggaidaikan barang-barang yang bernilai seperti emas. Nasabah akan diberikan surat tanda gadai sebagai bukti dan ketika nasabah ingin melunasi pinjaman/gadai maka bukti gadai diperlihatkan pada pihak Bank. Kedudukan gadai syariah (ar-Rahn) dalam sistim penggadaian di Indonesia belum sepenuhnya diakui keberadaanya, sedangkan potensi yang cukup kuat terutama daerah yang religius yang mayoritas muslim khususnya dan Indonesia mayoritas muslim, hanya saja karena prinsip (ar-Rahn) bagian dari prinsip perbankan syariah maka secara tidak langsung dapat dilakukan pada perbankan syariah. Sedangkan dalam tesis ini penulis lebih menekankan pada implementasi atau pelaksanaan sistim gadai emas pada PT Bank Sulselbar Syariah di Makassar. Akad gadai yang digunakan oleh Bank Sulselbar Syariah serta masalah yang terjadi ketika bank dan nasabah. Nasabah tidak mampu atau menunda untuk melunasi gadainya.

Tesis Marhanita dengan judul, "Tinjauan Yuridis Tentang Gadai Syariah (Rahn) Di Kantor Pegadaian Syari'ah Di Lhokseumawe. Tesis tersebut menekankan pada gadai syariah (rahn) berdasarkan Hukum Islam, pelaksanaan prinsip gadai syariah ( rahn) pada pegadaian syariah dan penyelesaian sengketa gadai ( $r a h n)$ pada pegadaian syariah di Lhokseumawe. Dari hasil penelitian ini adalah gadai syariah ( $r a h n$ ) berdasarkan Hukum Islam yang diberlakukan pada produk gadai syariah di pegadaian adalah tidak memungut bunga dalam berbagai bentuk karena riba, menetapkan uang sebagai alat tukar bukan sebagai komoditas yang diperdagangkan, dan melakukan bisnis untuk memperoleh imbalan atas jasa sebagai penerimaan labanya, yang dengan pengenaan bagi hasil dan biaya jasa tersebut menutupi seluruh biaya yang dikeluarkan dalam operasionalnya. Pelaksanaan prinsip gadai syariah (rahn) pada pegadaian syariah di Lhokseumawe berjalan di atas dua akad transaksi Syariah yaitu; Akad rahn dengan akad ini pegadaian menahan barang bergerak sebagai jaminan atas utang nasabah; dan Akad ijarah yaitu melalui akad ini dimungkinkan bagi pegadaian untuk menarik sewa atas penyimpanan barang bergerak milik nasabah yang telah melakukan akad. Pegadaian syariah di Lhokseumawe menyiapkan upaya penyelesaian sengketa apabila rahn wanprestasi yaitu dengan jalan musyawarah, bila tidak tercapai dengan musyawarah, maka penyelesaian sengketa tersebut sepakat untuk menyelesaikannya melalui Badan Arbitrase Syariah Nasional. Hal ini tentu berbeda dengan tesis ini, karena dari objek penelitian terdapat perbedaan yaitu lembaga keuangan non bank yaitu pegadaian syariah sedangkan yang ingin diteliti penulis lembaga keuangan bank yaitu Bank Sulselbar Syariah. Dalam tesis ini kajiannya lebih spesifik pada gadai emasnya ( $r a h n)$ serta dalam tesis ini tetap mengkaji tentang prinsip atau akad yang digunakan pada PT Bank Sulselbar Syariah di Makassar.

Bank Syariah dari teori dan praktik, oleh Muhammad Syafi'i Antonio, buku ini secara umum menyajikan pembahasan tentang universalitas islam, perkembangan sistem perbankan syariah, perbedaan mendasar dengan Bank Konvensional serta pembahasan antara bunga dan riba dalam perspektif ekonomi, serta prinsip-prinsip dasar perbankan syariah. 
Bank dan Lembaga Keuangan Syariah, oleh Andri Soemitro, buku ini memberikan paparan tentang pengertian dan perkembangan Bank Syariah dan lembaga keuangan non bank yang berprinsip syariah disertai kegiatan usaha dan kebijakan pengembangan lembaga keuangan di Indonesia. Lembaga Keuangan Islam, Tinjauan Teoritis oleh Nurul Huda, Muhammad Heykal, garis besar pembahasan buku ini pada prinsip operasional perbankan islam serta akad dan produk bank islam di berbagai negara.

Akad dan Produk Bank Syariah, oleh Ascarya, buku ini memberikan pembahasan secara komprehensif tentang dasar keuangan Islam, akad perbankan syariah dan produk-produk perbankan syariah serta praktik perbankan syariah yang berada di luar Indonesia. Buku ini mengambil suatu perbandingan perbankan syariah lainnya dan memberikan gambaran tentang prinsip-prinsip perbankan syariah.

\section{METODE PENELITIAN / METHODS}

Penelitian ini adalah termasuk jenis penelitian lapangan (field research) yaitu penelitian yang digunakan untuk mengungkapkan, menggambarkan dan menguraikan suatu masalah sebagaimana adanya, sehingga hanya merupakan penyingkapan fakta, (Nawawi, 1998) dalam arti penulis hanya memberikan realitas di lapangan secara sistematis yakni implementasi gadai emas di PT Bank Sulselbar Syariah di Makassar

Lokasi penelitian adalah bertempat di Makassar pada lembaga keuangan syariah yang diberi nama PT Bank Sulselbar Syariah yang terletak di Jalan Dr. Ratulangi No.7. Bank ini merupakan Bank Pemerintah Daerah Sulawesi Selatan yang beroperasi secara syariah salah satu prodak yang ditawakannya adalah gadai emas berkah iB (islamic banking) inilah yang akan diteliti oleh peneliti. Wawancara adalah proses tanya jawab dalam penelitian yang berlangsung secara lisan dimana dua orang atau lebih bertatap muka mendengarkan secara langsung informasi-informasi atau keterangan-keterangan dengan mengadakan tanya jawab secara langsung pada pihak yang berwenang, dalam hal ini pemimpin atau staf PT Bank Sulselbar Syariah di Makassar yang menagani persoalan gadai. Mewawancarai bapak Hartani Djurnie selaku pemimpin Bank Sulselbar Syariah Makassar, mewawancarai Petugas Penaksir bapak Sutrisno, mewawancarai bapak Irfan Hidayat selaku asisten administrasi, dan mewawancarai ibu Zahra Abd. Rasyid selaku pempinan seksi umum persenolia. Mewawancarai Ketua Dewan Pengawas Syariah Sulawesi Selatan dalam pengawasan terhadap implementasi gadai emas berkah iB (islamic banking) yang di lakukan oleh Bank Sulselbar Syariah.

\section{HASIL DAN PEMBAHASAN / DISCUSSION}

\section{Mekanisme Gadai Emas pada PT Bank Sulselbar Syariah di Makassar.}

PT Bank Sulselbar Syariah meluncurkan produk rahn atau gadai emas berkah iB (islamic banking), untuk mendukung peningkatan perolehan laba. Pemimpin Grup Unit Usaha Syariah Bank Sulselbar Sukiman mengatakan. produk rahn merupakan produk alternatif yang diperuntukkan bagi para nasabah yang ingin mendapatkan pinjaman, dengan syarat menyerahkan barang jaminan berupa emas. Kontruksi dari produk ini adalah, bank memberikan fasilitas pinjaman ( $q a r d h)$ yang harus dikembalikan tetap senilai pinjaman. 
Atas pinjaman tersebut, pihak bank meminta barang jaminan milik nasabah berupa emas, sebagai jaminan utang atau rahn yang disimpan pada bank. Lalu atas penyimpanan tersebut, bank menyewakan jasa penitipan atau pemeliharaan agunan, agar aman pada saat diserahkan kembali yang disebut dengan ijarah atau sewa. Sektor konsumsi segmen nasabah produk menurutnya, nasabah dengan latar belakang ibu rumah tangga untuk memenuhi kebutuhan konsumsinya. Selain sektor konsumsi, produk ini dapat juga dimanfaatkan bagi para pelaku usaha yang ingin menambah modal kerjanya dengan nominal tertentu.

A. Analisis Pinjaman

1. Petugas bank memeriksa kelengkapan dan kebenaran syarat-syarat calon pemohon peminjam.

2. Penaksir melakukan analisa yang mencangkup :

- Data pemohon (rahn)

- Analisa keaslian dan karatase jaminan berupa emas

- Analisa sumber pengembalian pembiayaan

- Lakukan proses Sistem Informasi Debitur (SID) untuk mengetahui track record nasabah.

3. Jika berdasarkan analisa petugas bank, timbul keragu-raguan baik terhadap keaslian emas, identitas pemohon, kemampuan pembayaran pinjaman dan cara perolehannya (tidak sesuai dengan syariah) maka dilakukan penolakan permohonan secara lisan dengan santun dan bijaksana.

4. Jika berdasarkan analisa, pemohon layak menerima pinjaman gadai emas berkah iB, maka bank akan menerbitkan sertifikat gadai emas berkah iB.

5. Dalam pelunasan pinjaman nasabah harus melakukan pelunasan pada saat jatuh tempoh.

B. Proses Realisasi

1. Pinjaman dapat di cairkan setelah akad pinjaman gadai emas berkah iB ditandatangani oleh pemohon dan pejabat bank yang berwewenag.

2. Jumlah pinjaman dibayarkan ke rekening nasabah, setelah pemohon/nasabah menyelesaikan biaya sewa yang sudah di hitung oleh pihak bank.

3. Apabila nasabah belum memiliki rekening Bank Sulselbar Syariah maka nasabah akan melakukan pembukaan rekening.

C. Biaya dan Limit Pinjaman (Vinancing to Valau)

1. Biaya sewa penyimpanan emas ditetapkan dalam Surat Edaran Direksi tersendiri. Biaya sewa penyimpanan emas Bank Sulselbar Syariah Makassar per gram adalah Rp 5.100,-

2. Biaya administrasi dalam proses gadai emas berkah iB adalah sebesar Rp 20.000,-

3. Biaya materai merupakan beban nasabah

4. Limit pinjaman (financing to valau) yang merupakan perbandingan antara jumlah pinjaman yang diterima oleh nasabah dengan nilai emas yang diagunkan oleh nasabah kepada bank, paling banyak adalah sebesar $80 \%$ (delapan puluh persen) dari rata-rata harga jual emas 100 (seratus) gram dan harga beli kembali ( bybeck ) emas PT ANTAM (Pesro) Tbk.. Harga emas tetap mengacu pada PT ANTAM karna PT ANTAM adalah perusahaan yang bergelut di bidang emas dan sudah teruji.

5. Pembiayaan gadai emas pada Bank Sulselbar Syariah maksimal adalah Rp 250.000.000,-

6. Adapun contoh perhitungannya misalnya : nasabah memiliki emas seberat 70 gram. Harga emas berdasarkan PT ANTAM (Persero) Tbk, sebagai berikut : 
- Harga jual emas 1 gram sebesar Rp 550.000,- (lima ratus lima puluh ribuh rupiah) per gram.

- Harga beli kembali (byback) emas sebesar Rp 540.000,- (lima ratus empat puluh ribu rupah) per gram.

- Perhitungan FTV(Financing To Value) adalah perbandingan antara jumlah pembiayaan yang diterima nasabah dengan nilai emas yang diagunkan nasabah kepada Bank. Perhitungannya untuk nasabah berdasarkan harga yang ditetapkan PT ANTAM (Persero) Tbk, sebagai berikut :

FTV $=80 \% \times$ [70 gram $\mathrm{x}($ harga jual + harga beli $) / 2]$

$=80 \% \times[70$ gram $\times(\operatorname{Rp} 550.000+\operatorname{Rp} 540.000) / 2]$

$=80 \% \times[70$ gram $\times$ Rp 545.000,-]

$=80 \% \times \mathrm{Rp} 38.150 .000,-$

$=\mathbf{R p} 30.520 .000,-$

- Dari hasil perhitungan diatas nasabah berhak mendapatkan pinjaman dengan berat emas 70 gram sebesar Rp. 30.520.000,-

7. Perhitungan biaya sewa atau biaya pemeliharaan atas barang emas yang dijaminkan harus didasari oleh berat jaminan emas tersebut bukan didasari pada jumlah pinjaman yang diterima nasabah. Adapun contoh perhitungan biaya sewa adalah :

- Biaya sewa sebesar Rp 5. 100,- per gram

- Jangka waktu pinjaman 4 bulan

- $\quad$ Biaya sewa $=(\operatorname{Rp} 5.100,-$ x 70 gram $) \times 4$ bulan

Biaya sewa $=357.000,-$ x 4

$$
\text { = Rp. 1.428.000,- }
$$

- Biaya sewa yang harus dibayar nasabah dengan menjaminkan emas seberat 70 gram ke pihak bank sebesar Rp. 1. 428.000,-

- Biaya sewa dalam perbulan dipotong/dibayarkan pada saat transaksi selama banyaknya bulan agar supaya pihak bank tidak lagi melakukan penagihan biaya sewa (ijarah). Sehingga nasabah fokus pada pengembalian pijnaman pokok bukan pada sewa titipan. Hal ini dilakukan bank sebagai usaha kehati-hatian untuk menghidari resiko.

Dalam mekanisme taksiran gadai emas pada Bank Sulselbar Syariah adalah beberapah metode/ tekhnik untuk mengetahui kadar emas serta mengetahui barang (emas) palsu dan yang asli. Dengan demikian bank tidak terkena pada resiko proses gadai emas. Dalam proses taksiran di butuhkan ketelitian untuk menganalis jaminan (emas) yang akan di gadaikan nasabah ke pihak bank. Adapun metode atau cara yang dilakukan Bank Sulselbar Syariah Makassar dalam melakukan taksiran agar bank terhindar dari resiko dengan mengunakan langkah-langkahdi bawah ini sebagai acuan dasar untuk mengetahui kadar emas serta karat emas diantaranya :

A. Sistem Penyebutan Kadar

Sistem penyebutan kadar ini dilakukan agar bank mampun untuk mengetahui kadar suatu emas serta karat emas. Sehingga bank mampu untuk menghitung berapa biaya yang akan diberikan kepada nasasabah. Adapun penyebutan kadar dapat dilihat pada tabel di bawah ini :

Tabel : 1.1 Penyebutan Kadar Emas

Kandungan Emas $\quad$ Sistem Penyebutan




\begin{tabular}{|c|c|c|}
\hline & $\begin{array}{c}\text { Per } \\
\text { Ribuan/ Eropa }\end{array}$ & Karat/ Amerika \\
\hline $99.99 \%$ & 999 & 24 \\
\hline $95.83 \%$ & 958 & 23 \\
\hline $91.65 \%$ & 916 & 22 \\
\hline $87.50 \%$ & 875 & 21 \\
\hline $83.33 \%$ & 833 & 20 \\
\hline $79.16 \%$ & 792 & 19 \\
\hline $75.00 \%$ & 750 & $\mathbf{1 8}$ \\
\hline $70.80 \%$ & 708 & 17 \\
\hline $66.70 \%$ & 667 & 16 \\
\hline
\end{tabular}

Keterangan :

- Ada penyebutan eropa pada setiap karat/kadar emas misalnya 958 berati kandungan emas 95,83\%. Sedangkan penyebutan Amerika pada setiap emas biasanya tertulis 23, ini menandakan emas tersebut memiliki kandungan 95, 83\% atau 985 untuk sebutan kadar Eropa. Bank Sulselbar Syariah menerima gadai emas minimal 18 karat Amerika atau kandungan emas $75.00 \%$ apabila dibawah dari 18 karat maka bank tidak melakukan pembiayaan gadai emas.

Campuran logam lain dalam perhiasan menetukan karat serta warnah perhiasan. Adapun emas dipasaran pada umumnya terdiri dari tiga bagian besar diantaranya :

1. Emas KUNING (mengandung perak/ Ag)

2. Emas MERAH (mengandung tembaga/ $\mathrm{Cu}$ )

3. Emas PUTIH (paduan emas + pladium)

Contohnya perhiasan emas 18 karat dapat dibuat macam warna sesuai daftar tabel di bawah ini :

Tabel : 1.2 Warna Kandungan Emas

\begin{tabular}{|l|l|l|c|}
\hline $\begin{array}{c}\text { Emas } \\
(\text { Au) }\end{array}$ & Perak (Ag) & Tembaga (Cu) & Warna \\
\hline $75 \%$ & $9 \%$ & $16 \%$ & Merah Muda \\
\hline $75 \%$ & $16 \%$ & $9 \%$ & Kuning Pucat \\
\hline $75 \%$ & $4,5 \%$ & $20,5 \%$ & Merah \\
\hline $75 \%$ & $15 \%$ Pladium & $5 \%$ Seng $+5 \%$ Platinium & Putih \\
\hline
\end{tabular}

Keterangan :

- Warna perhiasan emas tidak menentukan tinggi rendahnya kadar emas dalam suatu perhiasan.

B. Metode Pengujian Kadar Emas

1. Metode pengujian kualitatif

a. Jarum Uji Emas (touch stone) 
Mekanisme dan prisip untuk melakukan pengujian ialah membandingkan kecepatan pelarutan goresan barang yang akan diuji terhadapa kecepatan pelarutan goresan jarum uji yang sudah diketahui karatnya.

- Pengujian karat emas dengan mempergunakan jarum uji emas diperlukan :

- Pengalaman dan ketajaman mata.

- Mempunyai alat-alat uji yang memenuhi syarat.

- Megetahui syarat-syarat dan tata cara pengujiannya.

- Peralatan yang diperlukan terdiri dari :

- Jarum Uji Emas. Biasanya terdiri atas 10 jenis karatase : 14-24 karat

- Batu Uji Emas. Batu ini seperti batu tulis dengan warna hitam dan tidak mengandung kapur.

- Air Uji Emas. Airnya terdiri dari :

- Asam Nitrat (HNO3) dengan BJ = 1,316

- $\quad$ Asam Clorida (HCL) dengan BJ = 1,15

- Prosedur cara jarum uji emas diantaranya :

- Goreskan barang yang akan diuji pada batu uji dengan panjang dan lebar secukupnya sampai jelas warnanya, dengan arah dan tekanan yang sama (standar 9 kali goresan.

- Oleskan air uji emas (Asam Nitrat) pada goresan-goresan barang dibatu uji dan perhatikan reaksinya.

- Jika barang tersebut dimakan oleh air uji dapat disimpulkan bahwa barang tersebut bukan emas atau emas berkadar rendah (kurang dari 16 karat atau 67 $\%)$. Terjadi reaksi logam dengan Asam Nitrat. Bila tidak dimakan berarti emas diatas $67 \%$.

- Ada beberapa catatan dalam pengujian metode Touch Stone, dan harus di perhatikan dalam melakukan pengujian di antaranya ;

- Jangan mengosok perhiasan pada tempat patrian atau mudah putus/lepas.

- Sedapat mungkin menggosok bagian yang sukar terlihat.

- Menggosok barang pada beberapa tempat beberapa kali.

- Teliti tingkat keasliannya dengan memperbandingkan antara besar atau volume barang dengan beratnya.

- Perhatikan pula warna emas

- Apabila ada indikasi yang meragukan agar melakukan pengulangan pengujian.

b. Tes Berat Jenis (densty)

Prinsip : Untuk menguji apakah suatu barang mengandung emas/perak atau tdak harus mengetahui berat jenis logam perhiasan serta selain logam mulia.

- Berat jenis logam

Setiap logam memiliki berat jenis yang berbeda sehingga seseorang mampu untuk membedakan suatu logam tercampur dengan logam yang lain. Adapun berat jenis logam perhiasan dapat dilihat pada tabel dibawah ini :

Tabel : 1.3 Berat Jenis Logam Mulia

\begin{tabular}{|c|c|}
\hline NAMA LOGAM & BERAT \\
\hline Emas (Au) & $19,3 \mathrm{gr} / \mathrm{cc}$ \\
\hline Perak (Ag) & $10,5 \mathrm{gr} / \mathrm{cc}$ \\
\hline Platina (Pt) & $21,4 \mathrm{gr} / \mathrm{cc}$ \\
\hline
\end{tabular}


- Berat jenis logam selain logam mulia adalah:

Berat jenis selain logam muliah dapat dilihat melalui tabel dibawah ini :

Tabel 1: 4 Berat Jenis Selain Logam Mulia

\begin{tabular}{|c|c|}
\hline NAMA LOGAM & BERAT \\
\hline Nikel (Ni) & $8,9 \mathrm{gr} / \mathrm{cc}$ \\
\hline Besi (Fe) & $7,8 \mathrm{gr} / \mathrm{cc}$ \\
\hline Tembaga $(\mathbf{C u})$ & $8,88 \mathrm{gr} / \mathrm{cc}$ \\
\hline Timah Putih $(\mathbf{S n})$ & $7,3 \mathrm{gr} / \mathrm{cc}$ \\
\hline
\end{tabular}

- Peralatan yang di perlukan adalah sebagai berikut :

- Spiritus

- Air bersih/Aquadest/Air suling

- Timbagang

- Gelas ukur atau bejana

- Dalam mencari berat jenis memerlukan kesabaran dan ketelitian. Untuk mendapatkan hasil yang sempurnah harus memenuhi langka-langkah dibawa ini :

- Air yang digunakan harus besih.

- Timbangan harus dalam keadaan bersih.

- Timbangan tidak boleh kena angin (diletakan di dalam lemari kaca).

- Benda yang di cari BJ harus bersih.

- Benda tidak boleh bermata atau kosong (berongga).

- Seluruh benda harus masuk dalam air tetapi jangan menyentuh dasar dinding bejana/gelas ukur.

- Gelembung udara yang mungkin melekat pada benda harus dihilangkan.

- Cara menghitung harus teliti, hitung sampai dua angka dibelakang koma.

- Prosedur perhitungan berat jenis diantaranya adalah:

- Timbang benda pada timbangan (berat kering)

- Timbang benda dalam air pada tempat/bejana (berat basah).

- Gantung benda dengan tali, kemudian celupkan benda kedalam air sampai seluruh benda tercelup tetapi tidak menyentuh sisi atau dasar bejana (volume barang).

- Penentuan berat jenis (density) dapat dihitung sebagai berikut :

$\mathrm{BJ}=$ Berat/ volume atau cocokan dengan data BJ yang mendekati BJ dalam daftar. (BJ/ Volume = berat kering -berat basah).

- Tentukan kadar/karat barang. Perhitungan ini merupakan perhitunga praktis, dengan mengabaikan ralat dan campuran yang dipakai dalam benda tersebut.

c. Gold Tester

- Prinsip kerja : proses elektro kimia dengan mengukur susutnya energi listrik antara barang yang diperiksa dengan kathoda pada dispenser atau pemanfaatan/ 
penggunaan energy listrik dalam proses electro-kimia. Proses energy diubah menjadi potensilistrik yang diproses secara computer yang bisa memperlihatkan hasil dan nilai kekuatan/ kadar emas (nilai karat).

- Gold tester ini hanya bis akan memberikan hasil yang akurat (tepat) bila bendal barang yang diperiksa mempunyai komposisi campuran atau umum yang strandar.

- Kadar karat ditujukan dengan system standar Amerika (karat) atau dengan system standar Eropa (per-ribiuan)

\section{Barang palsu}

Barang yang dibuat tidak dengan wajar atau curang tetapi menyerupai barang asli yang dimaksudkan untuk mendapatkan keuntungan. Dengan merekayasa pada BERAT perhiasan maupun pada KADAR emas. Ada beberapa kemungkinan pemalsuan atau rekayasa barang terdiri atas :

a. Barang kosong

Barang yang semula dibuat kosong dan di isi dengan dempul, kawat, atau bahan isisan lainnya (logam) baik di isi penuh atau sebagian sehingga menambah berat perhiasan.

Misalnya : Gelang keroncong dengan volume tertentu yang seharusnya sekitar 10 gram tetapi ketika ditimbang menjadi 15 gram.

b. Barang sepuhan

Logam bukan emas disepuh atau dilapisi tipis dengan logam emas sehinnga Nampak seperti emas.

c. Barang lapisan

Logam yang lebih murah harganya dilapisi dengan logam emas sehingga seolah-olah seperti terbuat dari emas.

d. Barang dari emas rupa-rupa

Barang yang dibuat dari bermacam-macam kekuatan/ kadar emas baik untuk maksud tertentu ataupun disengaja sebagai teknik pemalsuan.

Dengan tujuan adalah penipuan demi mendapatkan keuntungan semata.

3. Identifikasi barang palsu.

Proses indentifikasi atau memperkirakan jenis barang yang akan diperiksa/ ditaksir penting dilakukan sebelum proses pengujian emas. Ada beberapa langkah untuk mengidentifikasi serta menjadi perhatian yaitu :

a. Menilai kesesuaian barang

Para penilai agar membiasakan menimang-nimang barang diatas tangan sebelum ditimbang untuk memperkirakan kewajaran dan kesepadanan barang tersebut antara volume, kadar, dan beratnya.

Misalnya : Gelang ularan dengan kadar 22 karat biasanya mempunyai berat antara 3550 gram. Terasa ringan ditimbang ditangan, setelah ditimbang beratnya hanya 20 gram.

b. Bunyi nyaring

Umumnya barang perhiasan yang berkadar tinggi (lebih dari 22 karat) bila di jatuhkan pada permukaan yang keras akan berbunyi pekak (tidak nyaring) dan demikian sebaliknya.

Misalnya : Gelang dengan kadar 22 karat dijatuhkan diatas lantai berbunyi pekak ada kemungkinan sebagai barang palsu.

c. Bentuk fisik barang

Bila sesuatu perhiasan digengam keras atau dibengkokan menjadi kisut-kisut atau terdapat kisut-kisut maka barang tersebut ada kemungkinan barang palsu (lapisan). 
4. Cara pengujian barang palsu

Bila terdapat indikasi barang palsu maka lakukan pemeriksaan barang cemat dengan cara :

a. Tetapkan berat jenisnya.

b. Bila sulit menetukan berat jenisnya, maka lakukan pengujian sebagai berikut :

$\checkmark$ Barang diduga sepuhan; Lakukan pengosokan secara keras disuatu tempat beberapa kali.

$\checkmark$ Barang diduga terdiri dari rupa-rupa kadar; Gosok keras dibeberapa tempat.

$\checkmark$ Barang diduga lapisan; Pengujiannya dengan meng-cutter, dibor, dikikir, pada barangnya.

Perkembangan produk-produk berbasis syariah kian marak di Indonesia, tidak terkecuali lembaga perbankan. Bank Sulselbar Syariah di Makassar mengeluarkan produk berbasis syariah yang disebut dengan gadai emas berkah iB. Pada dasarnya, produk-produk berbasis syariah memiliki karakteristik seperti, tidak memungut bunga dalam berbagai bentuk karena riba, menetapkan uang sebagai alat tukar bukan sebagai komoditas yang diperdagangkan, dan melakukan bisnis untuk memperoleh imbalan atas jasa dan atau bagi hasil yang sesuai dengan syariat Islam. (Anwar, 2007) Denagan demikian dalam proses pelaksanaannya gadai ( $\mathrm{rahn}$ ) perlu dilakukan suatu tata cara perjanjian (akad) yang mengacu pada prisip-prinsip Al-qur'an dan Hadis.

Akad dalam lembaga keuangan syariah terdiri dari dua jenis akad yaitu : Akad tabarru' dan akda tijari. Akad tabarru' merupakan perjanjian atau kontrak yang tidak mencari keuntungan materiil hanya bersifat kebajikan murni diantaranya infaq dan waqaf. Sedangkan akad tijari merupakan perjanjian atau kontrak yang bertujuan mencari keuntungan usaha seperti akad yang mengacu pada konsep jual beli yaitu akad murabahah, salam, dan istisna'. Akad yang mengacu pada bagi hasil yaitu Akad Mudharabah dan musyarakah. Akad yang mengacu pada konsep sewa yaitu akad ijarah, dan ijarah muntahiyah bittamlik dan akad yang mengacu pada konsep titipan yaitu akad wadi'ah yad al-amanah mengamanahkan titipan kepada pihak yang di percaya dalam hal ini lembaga keuangan syariah.

Akad-akad yang dipergunakan oleh perbankan syariah di Indonesia dalam operasinya merupakan akad-akad yang tidak menimbulkan kontroversi yang disepakati oleh sebagian besar ulama dan sudah sesuai dengan ketentuan syariah untuk ditetapkan dalam produk dan instrument keuangan syariah yang ditawarkan kepada nasabah. Akad-akad tersebut meliputi akad-akad untuk pendanaan, pembiayaan, jasa produk, jasa operasional, dan jasa investasi. (Ascarya, 2007)

Dari beberapa akad yang yang telah disepakati sebagian besar para ulama inilah yang menjadi landasan/ acuan hukum bagi Bank Sulselbar Syariah Makassar untuk melakukan operasional sehingga tidak bertentangan dengan Al-quran dan Hadis. Dalam pelaksanaan akad qardh yang dipakai dala dalam pembiayaan selama mengikuti atau mengacu pada Fatwa Dewan Pengawas Syariah Nasional maka bisa diaplikasikan. 


\section{KESIMPULAN}

Berdasarkan penelitian yang peneliti lakukan dan analisis data yang diperoleh dari obyek penelitian, maka dapat disimpulkan bahwa:

Proses implementasi gadai emas berkah iB pada Bank Sulselbar Syariah telah menjalankan gadai secara syariah. Dalam pelayanan Bank Sulselbar Syariah Makassar mengunakan prinsipprinsip kehati-hatian dengan proses nasabah mengadai emasnya ke bank dan bank memberikan nilai (uang) terhadap jaminan, nasabah berkewajiban membayar biaya sewa atau pemeliharaan barang (emas) yang dititipkan kepada bank. Inilah menjadi daya tarik kepada nasabah agar merasa nyaman dan tetap loyal menjadi mitra bank. Hal ini telah dibuktikan dengan akad yang digunakan tetap mengacu pada Fatawa Dewan Syariah Nasional tentang rahn dan qardh. Serta surat Edaran Bank Indonesia Nomor : 14/ DPbS Tahun 2012 perihal produk (qardh) beragun emas bagi Bank Syariah dan Unit-Unit syariah.

Akad yang dilakuka adalah akad qardh adalah pemberian harta kepada orang lain. Nasabah melakukan perjanjian pinjaman (qardh) kepada bank. Dengan membawa barang jaminan (emas). Dalam hal pemberian jaminan ke bank (murtahin) menyimpan barang yang digadaikan, dikarenakan barang yang digadaikan tersebut dititipkan dalam artian di sewa (ijarah) tempat penyimpanan milik bank dan nasabah dibebankan biaya penitipan/sewa selama waktu yang telah disepakati. Dalam Akad yang dilakukan Bank Sulselbar Syariah Makassar mengacu pada Fatwa Dewan Syariah Nasional Majelis Ulama Indonesia No : 92/DSN/MUI/IV/2014 tentang Pembiayaan yang disertai Rahn serta fatwa-fatwa yang berkaitan dengan rahn, rahn emas dan ijarah.

Dalam hal terjadi perbedaan penafsiran terhadap pelaksanaan akad ini maka para pihak sepakat untuk menyelesaikannya secara musyawara mufakat. Dalam hal tidak tercapai mufakat maka para pihak sepakat untuk menyelesaikannya melalui bandan Arbitrase atau melalui Peradilan Agama. Bank Sulselbar Syariah Makassar selama dalam pelaksanaan produk gadai emas berkah iB belum pernah bersengketa dengan nasabah. Dalam menyelesaikan masalah pihak bank lebih mengedepankan musyawara dan mufakat atara pihak bank dan nasabah, mencari solusi terbaik anatar kedua bela pihak. Adapun langkah yang ditempu Bank Sulselbar Syariah ketika terjadi permasalahan yaitu melalui negosiasi, medias, konsiliasi, dan Arbitrase antara kedua belah pihak yang bersengketa. 


\section{DAFTAR PUSTAKA}

Anwar, S. (2007). Hukum Perjanjian Syariah. Jakarta.

Arifin, Z. (2005). Dasar-Dasar Manajemen Bank Syariah. Jakarta: Pustaka Alfabet.

Ascarya. (2007). akad dan produk bank syariah. Jakarta: Rajagrafindo.

Dahlina, R. (2005). lembaga gadai syariah bank muamalat cab. medan. jurnal kenotarisan.

Marhanita. (2012). Tinjauan yuridis gadai syariah di Lhoksumawe. jurnal hukum.

Nasution, M. E. (2010). Pengenalan Ekonomi Islam. Jakarta: Kencana.

Nawawi, H. (1998). metode penilitian sosial. Yogyakarta: UGM Press.

Sholahuddin. (2006). Lembaga Ekonomi dan keuangan Islam. Surakarta: Muhammadiyah Universty Press.

Soemitra, A. (2009). bank dan Lembaga keuangan syariah. Jakarta: Prenada Media group.

Sulselbar, B. (2005). buku pedoman mekanisme taksiran gadai emas berkah iB.

Sulselbar, B. (n.d.). bank sulselbar. Retrieved from bank sulselbar: http://www.banksulselbar.co.id/corporate-site/gadai

Sulselbar, B. (n.d.). buku pedoman ketentuan umum gadai emas iB pada bank sulselbar syariah Makassar.

Suryati. (n.d.). Implementasi ar-rahn di unit pegadaian syariah bangkalan. jurnal kajian ekonomi.

Susilowati, T. P. (2008). pelaksanaan gadai dengan sistem syariah semarang. jurnal kenotarisan . 